\title{
Detection of gyrA and parC Mutations and Prevalence of Plasmid-Mediated Quinolone Resistance Genes in Klebsiella pneumoniae
}

This article was published in the following Dove Press journal: Infection and Drug Resistance

\author{
Sawsan Mohammed Kareem, \\ Israa MS Al-kadmy, (D) ${ }^{1,2}$ \\ Saba S Kazaal, (D) ' \\ Alaa N Mohammed Ali, \\ Sarah Naji Aziz,' \\ Rabab R Makharita, (iD) ${ }^{3}$ \\ Abdelazeem M \\ Algammal, (iD ${ }^{4}$ Salim Al-Rejaie, ${ }^{5}$ \\ Tapan Behl, (iD ${ }^{6}$ Gaber El- \\ Saber Batiha, 7 Mohamed A El- \\ Mokhtar, (iD) ${ }^{8}$ Helal F Hetta (iD) 8,9 \\ 'Branch of Biotechnology, Department of Biology, \\ College of Science, University of Mustansiriyah, \\ Baghdad, Iraq; ' ${ }^{2}$ aculty of Science \& Engineering. \\ School of Engineering, University of Plymouth, \\ Plymouth, PL4 8AA, UK; 'Botany Department, \\ Faculty of Science, Suez Canal University, Ismailia, \\ 41522, Egypt; ${ }^{4}$ Department of Bacteriology, \\ Immunology and Mycology, Faculty of Veterinary \\ Medicine, Suez Canal University, Ismailia, 41522, \\ Egypt; ${ }^{5}$ Department of Pharmacology \& \\ Toxicology, College of Pharmacy, King Saud \\ University, Riyadh, Saudi Arabia; ${ }^{6}$ Chitkara College \\ of Pharmacy, Chitkara University, Rajpura, Punjab, \\ India; ${ }^{7}$ Department of Pharmacology and \\ Therapeutics, Faculty of Veterinary Medicines, \\ Damanhour University, Damanhour, 225 I I, Egypt; \\ ${ }^{8}$ Department of Medical Microbiology and \\ Immunology, Faculty of Medicine, Assiut University, \\ Assiut, 71515, Egypt; ${ }^{9}$ Department of Internal \\ Medicine, University of Cincinnati College of \\ Medicine, Cincinnati, Ohio, USA
}

Background and Aim: Recently, the extensive use of quinolones led to increased resistance to these antimicrobial agents, with different rates according to the organism and the geographical region. The aim of this study was to detect the resistance rate of Klebsiella pneumoniae Iraqi isolates toward quinolone antimicrobial agents, to determine genetic mutations in gyrA and parC, to screen for efflux-pump activity, and to screen the presence of plasmid-mediated quinolone resistance (PMQR) genes.

Methods: Forty-three K. pneumoniae isolates were confirmed phenotypically and genotypically by Vitek 2 system and species specific primers by PCR using the targeting rpo gene followed by sequencing. Antibiotic susceptibility test was carried out using disc diffusion method. Quinolone resistant isolates were subjected to ciprofloxacin MIC testing, and cartwheel method to screen for efflux pump activity. The presence of the plasmid mediated quinolone resistance genes $q e p A, q n r B$, qnrS, and $a a c(6) I b$ was tested by PCR. Sequencing of gyrA and parC was performed.

Results: We observed a high rate of resistance to ceftriaxone, gentamicin ciprofloxacin, and levofloxacin. Low rate of resistance was detected against amikacin and azithromycin. Ciprofloxacin MIC results revealed that $96.1 \%$ of the isolates had MICs $>256 \mu \mathrm{g} / \mathrm{mL}$, $83.4 \%$ had MICs $>512 \mu \mathrm{g} / \mathrm{mL}$ while $34.6 \%$ had MIC $>1024 \mu \mathrm{g} / \mathrm{mL}$. Testing of isolates against ciprofloxacin mixed with $\mathrm{EtBr}$ at various concentrations resulted in decreased resistant. Sequencing results showed that Ser83Leu was the most common mutation in gyrA that was observed in all quinolone resistant isolates, followed by Asp87Asn. Ser80Ile mutation in $\operatorname{parC}$ was observed in $77.7 \%$ of the tested isolates. The prevalence of PMQR genes was $92.5 \%$ aac (6)-Ib, 51.8\% qnr B, 40.7\% qep A, and 37\% qnrS.

Conclusion: Quinolone resistance is common in K. pneumoniae isolates in Baghdad. The frequent mutation in gyr A and $\operatorname{parC}$, and the presence of $\mathrm{PMQR}$ genes is alarming.

Keywords: MDR K. pneumoniae, quinolones resistance gene, PMQR

\section{Introduction}

Due to the rapid emergence and spread of resistance to antibiotics, it is urgent to monitor the use of antibiotics and determine the ways of treatment to minimize the random and miss use of antibiotics. ${ }^{1-5}$ Therefore, it is very important to continue studying genes that responsible for the resistance to different antibiotics in pathogenic bacteria; including genes that responsible for quinolone resistance. ${ }^{6-11}$

Klebsiella pneumoniae (K. pneumoniae) is a leading cause of hospital and community-acquired infections. ${ }^{12,13}$ Quinolones are commonly used and effective antibiotics for
University of Cincinnati College of Medicine, Department of Internal Medicine, PO Box 670595, Cincinnati, OH, 45267-0595, USA Email helal.hetta@uc.edu

Israa MS Al-kadmy

Faculty of Science \& Engineering, School of Engineering, University of Plymouth, Drake Circus, Plymouth, PL4 8AA, United Kingdom Email israa.al-kadmy@plymouth.ac.uk 
treatment of multidrug resistant bacteria. ${ }^{14,15}$ However, clinical isolates of $K$ pneumoniae that are resistant to multiple antibiotics, including fluoroquinolones have frequently been described. ${ }^{16-18} \mathrm{~K}$. pneumoniae can resist antibiotic action through several mechanisms including drug inactivation, target alteration, increased efflux pump activity, and decreased cell permeability. ${ }^{19}$ Resistance to quinolones is mediated mainly by mutations in the quinolone resistance-determining regions (QRDR), particularly in gyrA and parC genes, which leads to structural changes in DNA gyrase and/or topoisomerase IV, that reduces the affinity to fluoroquinolones. ${ }^{20}$ Additional mutation can occur in genes that regulate efflux pumps activity. ${ }^{21}$

In the past, quinolones resistance was believed to be mediated by bacterial chromosomal mutations till 1998 when the researchers discovered plasmid mediated genes in K. pneumoniae, named "qnr" encoding to pentapeptide repeat family which play a role in binding and protecting DNA gyrase, and topoisomerase IV from repression by ciprofloxacin. $^{21-23}$ Then four major groups of $q n r$ genes ( $q n r \mathrm{~A} q n r \mathrm{~B} q n r \mathrm{C}$ and $q n r \mathrm{~S})$ and two plasmid-mediated quinolones resistance (PMQR) genes aac (6 $\left.6^{\prime}\right)-I b-c r$ and another qepA encoding various aminoglycoside transferases that modify ciprofloxacin to facilitate an efflux pump protein were identified. $^{20,24}$ Bifunctional acetyltransferase protein coded by aac(6')-bI-cr acetylate amino nitrogen in the piperazinyl group of fluoroquinolones such as norfloxacin, ciprofloxacin, and aminoglycoside such as amikacin and kanamycin. ${ }^{25}$ This gene commonly exist in multi-resistance plasmids as a cassette in integrin. ${ }^{26}$

Bacteria can resist the hydrophilic fluoroquinolones such as norfloxacin and ciprofloxacin by plasmid mediated efflux pump QepA which is the major group of facilitator family, exist in plasmid encoding to aminoglycoside ribosomal methylase $r m t \mathrm{~B} .{ }^{27-29}$ Increasing prevalence of PMQR have been reported worldwide in clinical isolates of K. pneumoniae, however, no detailed reports of the quinolone resistance and it mechanism have been described in Iraq. The aim of this study was to detect the resistance rate of Klebsiella pneumoniae Iraqi isolates toward quinolone antimicrobial agents, to determine genetic mutations in gyrA and parC, to screen for efflux-pump activity, and $\mathrm{PMQR}$ genes.

\section{Materials and Methods}

\section{Ethics Statement}

The research was done as per the ethical guidelines of the Declaration of Helsinki 1975 and was approved by the
Mustansiriyah University ethics committee. Informed written consent was taken from all recruited subjects.

\section{Isolation and Identification of}

\section{K. pneumoniae}

Forty-three bacterial isolates from Klebsiella pneumoniae were collected between June and December 2019. These isolates were obtained from patients attending medical care services in Baghdad hospitals, Medical city hospital, Ibn Balady hospital, Al-Zahra hospital and Al-Yarmok hospital in Baghdad city. The isolates were distributed among thirteen isolates from wound infection, eight isolate was from a blood stream infection, eight from a urinary tract infection, five isolates from burn, four isolates from ear, three from sputum, one from each of fluid, and bronchial infection. Bacterial identification was based on morphological and biochemical tests, Vitek 2 system, followed by PCR and sequencing for rpo gene (housekeeping gene), the oligonucleotide sequence of rpoB primers are listed in Table 1. PCR products of representative samples were sequenced and submitted to GenBank under accession numbers ATB17136.1, ATB17140.1 and ATB17139.1.

\section{Antimicrobial Susceptibility Test and Minimum Inhibitory Concentration (MIC) for Ciprofloxacin}

The susceptibility to antimicrobial agents was performed by the using disc diffusion method and Muller-Hinton agar (MHA) according to the CLSI guidelines. ${ }^{30}$ Ten antimicrobial discs were used including: Ak, amikacin (30 $\mu \mathrm{g})$; GN, gentamicin $(30 \mu \mathrm{g})$; IMI, imipenem $(10 \mu \mathrm{g})$; FOX, Cefoxitin $(30 \mu \mathrm{g})$; CRO, Ceftriaxion $(30 \mu \mathrm{g})$; NOR, Norfloxacin $(10 \mu \mathrm{g})$; ATH, Azithromycin (15 $\mu \mathrm{g})$; LEV, Levofloxacin (5 $\mu \mathrm{g})$; AUG, Amoxicillin+Clavulanic acid (30 $\mu \mathrm{g})$ and CIP, Ciprofloxacin (5 $\mu \mathrm{g})$. MIC for ciprofloxacin was also performed by the standard agar dilution method for the 27-resistant isolates according to the CLSI criteria. According to CLSI guidelines, MIC values of $\geq 4$ $\mathrm{ug} / \mathrm{mL}$ were considered as resistant. ${ }^{30}$ Escherichia coli ATCC 25,922 was used as quality stander strain (Central Public Health Laboratory, Baghdad). MIC was recorded as the lowest concentration that inhibited bacterial division as evidenced by the absence of bacterial growth on the media.

\section{Phenotypic Detection of Efflux Pump-Mediated Resistance}

The phenotypic detection of Efflux pump mechanism was performed using EtBr-agar cartwheel (EtBrCW) method in 
Table I The Primers Used in the Current Study for PCR Amplification

\begin{tabular}{|c|c|c|c|c|}
\hline Target Gene & Primers $5-3$ & Size Products & $T_{m}$ & References \\
\hline gyrA & $\begin{array}{l}\text { F-AAATCTGCTCGTGTCGTTGG-3 } \\
\text { R- GCCATACCTACAGCAATACC-3 }\end{array}$ & 349bp & $52 \mathrm{C}$ & [35] \\
\hline parC & $\begin{array}{l}\text { F-AAGCCCGTACAGCGCCGTATT-3' } \\
\text { R' -AAAGTTATCTTGCCATTCGCT-3' }^{\prime}\end{array}$ & 327bp & $60 \mathrm{C}$ & [35] \\
\hline qepA & $\begin{array}{l}\text { F- AACTGCTTGAGCCCGTAGAT - } 3^{\prime} \\
\text { R - GTCTACGCCATGGACCTCAC - } 3^{\prime}\end{array}$ & 596bp & $54 \mathrm{C}$ & [36] \\
\hline$q n r B$ & $\begin{array}{l}\text { F-GATCGTGAAAGCCAGAAAGG -3' } \\
\text { R- ATGAGCAACGATGCCTGGTA - } 3^{\prime}\end{array}$ & 476bp & $52 \mathrm{C}$ & [36] \\
\hline qnrS & $\begin{array}{l}\text { F- GCAAGTTCATTGAACAGGGT- } 3^{\prime} \\
\text { R- TCTAAACCGTCGAGTTCGGCG- } 3^{\prime}\end{array}$ & $428 \mathrm{bp}$ & $60 \mathrm{C}$ & [36] \\
\hline$a a c\left(6^{\prime}\right)-\mid b-$ & $\begin{array}{l}\text { F- TTG CGA TGC TCT ATG AGT GGCTA } \\
\text { R- CTC GAA TGC CTG GCG TGT TT }\end{array}$ & 482bp & $56 \mathrm{C}$ & [43] \\
\hline rpoB & $\begin{array}{l}\text { F- GGC GAA ATG GCW GAG AAC - } 3^{\prime} \\
\text { R- GAG TCT TCG AAG TTG TAA - } 3 \text { ' }\end{array}$ & $1056 \mathrm{bp}$ & $50 \mathrm{C}$ & [35] \\
\hline
\end{tabular}

MHA plates by using Ciprofloxacin and EtBr stain. ${ }^{31}$ $\mathrm{EtBrCW}$ was done by using $\mathrm{EtBr}$ stain at concentration $(5,10,15,20,25 \mu \mathrm{L} / \mathrm{mL})$ to MHA plates containing ciprofloxacin ranging from 16 to $1024 \mu \mathrm{g} / \mathrm{mL}$ which prepared on the same day for experiment and protected from light, then the plates were swabbed with the bacterial inoculum starting from the center of the plate toward the edges, and then were incubated in dark space at $37^{\circ} \mathrm{C}$ for $18 \mathrm{hrs}$. Cultures were placed on ultraviolet transilluminator and photographed using a gel documentation system. The minimum concentration of EB that produced fluorescence of the bacterial mass was recorded, ${ }^{32}$ taking corresponding Escherichia coli ATCC 25,922 strains as negative controls.

\section{Detection of Plasmid-Mediated Quinolone Resistance Genes and Sequencing of gyrA and parC}

DNA was extracted according to Manufacture instructions (wizbio, Korea), genomic DNA was eluted by adding $50 \mathrm{~EB}$ buffer (10 mM Tris-HCL, pH 9, 0.5 Mm EDTA) and visualized by electrophoresis on horizontal gels containing $1 \%$ agarose and stained with ethidium bromide. Isolates with reduced susceptibility to ciprofloxacin were subjected to PCR screening to detect the $\mathrm{PMQR}$ genes $q e p \mathrm{~A} q n r \mathrm{~B} q n r \mathrm{~S}$, and $a a c(6) I b$. In addition, gyrA and $p a r \mathrm{C}$ in these isolates were amplified by PCR followed by sequencing. PCR mixture was prepared according to manufacture instructions (Promega/USA) by adding $3 \mu \mathrm{L}$ of DNA template, $1.5 \mu \mathrm{L}(0.6 \mathrm{pmol})$ of each forward and reverse primers, $12.5 \mu \mathrm{L}$ of $2 \mathrm{X}$ GO TaqGreen mastermix and finally completed the volume to $25 \mu \mathrm{L}$ by adding nuclease free water. Primer sequences and annealing temperatures are listed in Table 1. The amplification process was done by using thermocycler (TechNet-500/USA), the conditions of the PCR reaction included initial denaturation at $95 \mathrm{C}^{\circ} / 5 \mathrm{~min}$, repeated 35 cycles of denaturation $95 \mathrm{C}^{\circ} / 30 \mathrm{sec}$, annealing for $30 \mathrm{sec}$ and extension $72 \mathrm{C}^{\circ} / 1 \mathrm{~min}$. Then a final extension at $72 \mathrm{C}^{\circ} / 10 \mathrm{~min}$. PCR products for gyrA and $p a r C$ were subjected to sequencing analysis which was carried out by Macrogen DNA Sequencing (Seoul, Korea), and analyzed with NCBI database.

\section{Results}

\section{Isolation and Identification}

Forty three Klebsiella pneumoniae clinical isolates were collected from different sources in different hospitals in Baghdad. These isolates were collected from wounds $(\mathrm{n}=13,30.2 \%)$, blood $(\mathrm{n}=8,18.6 \%)$, UTI $(\mathrm{n}=8,18.6 \%)$, burns $(\mathrm{n}=5,11.6 \%)$, ear infections $(\mathrm{n}=4,9.3 \%)$, sputum $(\mathrm{n}=3,6.9 \%)$, and fluid and bronchial secretions $(\mathrm{n}=1,2.3 \%)$.

\section{Antibiotic Susceptibility Test}

The tested isolates showed different antibiogram resistance activities. Highly resistance was observed towards ceftriaxone $86.04 \%$ (37/43) and gentamicin 69.7\% (30/43). Resistance for both Ciprofloxacin and Levofloxacin was observed in $62.8 \%$ (27/43). Moderate resistance was observed to Amoxicillin +Clavulanic acid, Norfloxacin and Cefoxitin (55.8\% (24/43). 
$53.4 \%(23 / 43)$ of isolates were resistant to imipenem and $48.8 \%$ (21/43) to amikacin, while only 44.1\% (19/43) were resistant to Azithromycin (Figure 1).

The MIC was evaluated for the isolates which were ciprofloxacin resistant by disc diffusion $(n=27)$. These isolates were resistant to $16,32,64$, and $128 \mu \mathrm{g} / \mathrm{mL}$ of ciprofloxacin, while $25 / 27(96.1 \%)$ were resistant to $256 \mu \mathrm{g} / \mathrm{mL}$, and $23 / 27$ (83.4\%) were resistant to $512 \mu \mathrm{g} / \mathrm{mL}$. Finally, 9/27 (34.6\%) of isolates were resistant to $1024 \mu \mathrm{g} / \mathrm{mL}$. While, when we mixed Ciprofloxacin with Ethidium bromide (EtBr) for detection of efflux pump by agar cartwheel method, the results showed a decrease in resistance rates. The isolates showed $100 \%$ resistance to $(16,32,64 \mu \mathrm{g} / \mathrm{mL}$ with $\mathrm{EtBr}$, while decrease to $92.3 \%(24 / 27)$ in 128 and $256 \mu \mathrm{g} / \mathrm{mL}$ with EtBr, while reached $69.2 \%(18 / 27)$ in $512 \mu \mathrm{g} / \mathrm{mL}$ with EtBr. In presence of $1024 \mu \mathrm{g} / \mathrm{mL}$ ciprofloxacin with $\mathrm{EtBr}$, resistance reached $19.2 \%(5 / 27)$. Table 2 showed the distribution of efflux activity with various concentrations of EtBr. 10/27 isolates showed a presumptive overexpression of efflux pump activity. The minimum concentration of EtBr at which strains with efflux activity showed fluorescence was $512 \mu \mathrm{g} / \mathrm{mL}$.

Importantly, sequencing results showed that all quinolone resistant isolates $(27 / 27,100 \%)$ had the Ser83Leu substitution in gyrA, among which 24/27 (88.8\%) co-carried the Asp87Asn genetic alteration. parC sequencing showed a common mutation of Ser80Ile in 21/27 (77.7\%) and no other mutations were observed in the same gene (Table 2).

\section{Molecular Detection of Plasmid-Mediated Quinolone Resistance Genes}

Presence of PMQR genes was analyzed by PCR. The most predominant genes were aac (6)-Ib (25/27, 92.5\%), qnr B (14/27, 51.8\%), qepA (11/27, 40.7\%), and qnrS (10/27, 37\%) (Figure 2).

\section{Discussion}

Gram-negative bacilli, particularly K. pneumoniae, are major problematic organisms that have the ability to resist different types of antibiotics, including fluoroquinolones. ${ }^{33,34}$ These opportunistic multi-drug resistant bacteria represent a serious challenge to infectious disease specialists worldwide. ${ }^{35-42}$ Mechanisms of resistance to fluoroquinolones include mutations in their target proteins; DNA gyrase and topoisomerase IV, presence of PMQR determinants, expression of efflux pumps, and changes in permeability of the cell membrane. ${ }^{43-45}$

In the current study, a high rate of quinolone resistance was reported among K. pneumoniae (62.8\%), and most of the isolates had MICs $\geq 512 \mu \mathrm{g} / \mathrm{mL}$. The rate of resistance to fluoroquinolones varies according to the geographical distribution, e.g., resistance rates are $71.4 \%$ in Iran, $46.9 \%$ in Egypt, and $89 \%$ in India. ${ }^{46-48}$

The resistance to fluoroquinolones is mostly caused by mutations targeting the QRDR of gyrA, and parC of DNA gyrase and topoisomerase $\mathrm{IV}^{49}$ Sequencing of gyrA and $\operatorname{par} \mathrm{C}$

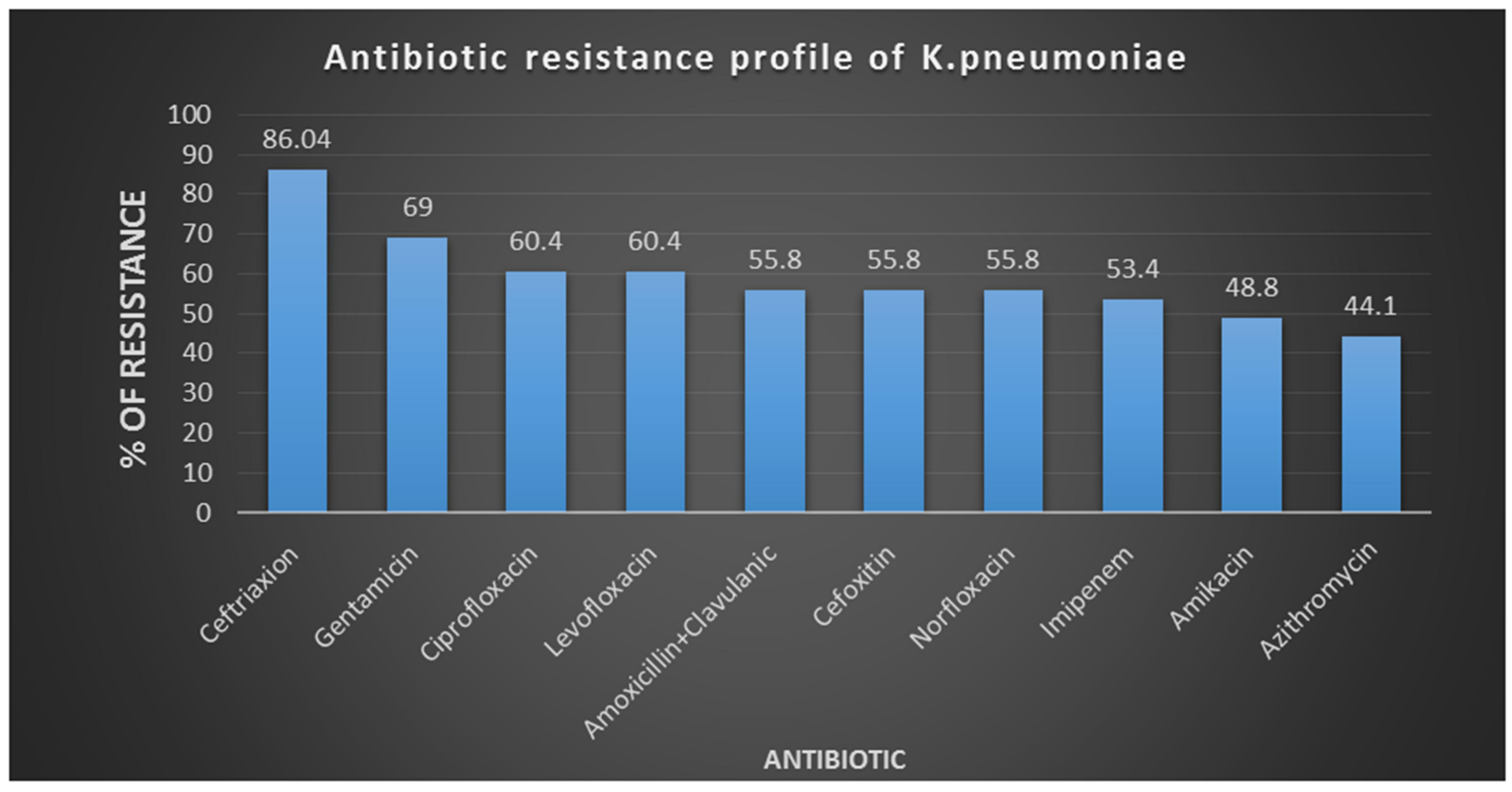

Figure I Antibiotic resistance profile of $K$. pneumoniae. 
Table 2 Efflux Activity at Varying Concentrations of Ethidium Bromide and Corresponding gyrA and parC Gene Mutations

\begin{tabular}{|c|c|c|c|c|c|}
\hline No & Isolate & $\begin{array}{l}\text { Concentration of EtBr + } \\
\text { Ciprofloxacin at Which } \\
\text { Bacteria Started to Fluoresce } \\
(\mu \mathrm{g} / \mathrm{mL})\end{array}$ & gyrA & parC & $\begin{array}{l}\text { Efflux } \\
\text { Activity }\end{array}$ \\
\hline I. & KI & 1024 & Ser83Leu, Asp87Asn & Ser80lle & + \\
\hline 2. & K3 & 512 & Ser83Leu, Asp87Asn & Ser80lle & + \\
\hline 3. & K6 & 512 & Ser83Leu, Asp87Asn & Ser80lle & + \\
\hline 4. & K9 & 64 & Ser83Leu, Asp87Asn & Ser80lle & - \\
\hline 5. & $\mathrm{~K} / 2$ & 1024 & Ser83Leu, Asp87Asn & Ser80lle & + \\
\hline 6. & $\mathrm{KI} 3$ & 512 & Ser83Leu, Asp87Asn & Ser80lle & - \\
\hline 7. & KI5 & 512 & Ser83Leu, Asp87Asn & Ser80lle & + \\
\hline 8. & KI7 & 512 & Ser83Leu, Asp87Asn & Ser80lle & + \\
\hline 9. & $\mathrm{~K} 18$ & 1024 & Ser83Leu, Asp87Asn & Ser80lle & - \\
\hline 10. & $\mathrm{~K} 19$ & 512 & Ser83Leu, Asp87Asn & Ser80lle & - \\
\hline II. & $\mathrm{K} 20$ & 512 & Ser83Leu, Asp87Asn & Ser80lle & - \\
\hline 12. & K2I & 512 & Ser83Leu, Asp87Asn & Ser80lle & - \\
\hline 13. & K23 & 512 & Ser83Leu, Asp87Asn & Ser80lle & - \\
\hline 14. & K25 & 512 & Ser83Leu, Asp87Asn & Ser80lle & - \\
\hline 15. & $\mathrm{~K} 26$ & 256 & Ser83Leu, Asp87Asn & Ser80lle & - \\
\hline 16. & K27 & 512 & Ser83Leu, Asp87Asn & Ser80lle & - \\
\hline 17. & $\mathrm{~K} 28$ & 512 & Ser83Leu, Asp87Asn & Ser80lle & - \\
\hline 18. & K29 & 256 & Ser83Leu, Asp87Asn & Ser80lle & - \\
\hline 19. & K30 & 256 & Ser83Leu, Asp87Asn & Ser80lle & + \\
\hline 20. & K3I & 512 & Ser83Leu, Asp87Asn & Ser80lle & - \\
\hline 21. & K32 & 64 & Ser83Leu, Asp87Asn & Ser80lle & - \\
\hline 22. & K33 & 512 & Ser83Leu, Asp87Asn & - & + \\
\hline 23. & K35 & 512 & Ser83Leu, Asp87Asn & - & + \\
\hline 24. & K36 & 512 & Ser83Leu, Asp87Asn & - & - \\
\hline 25. & K4I & 512 & Ser83Leu & - & - \\
\hline 26. & K42 & 512 & Ser83Leu & - & - \\
\hline 27. & K43 & 1024 & Ser83Leu & - & + \\
\hline
\end{tabular}

showed that all tested Klebsiella isolates exhibited a Ser83Leu mutation in the gyrA, which is consistent with previous studies. ${ }^{47,50}$ Moreover, most of the isolates had an additional Asp87Asn mutations in gyrA (88.9\%) and Ser80Ile mutation in $\operatorname{parC}(77.8 \%)$, which is associated with high level of ciprofloxacin resistance. ${ }^{51-53}$ Similar mutations were also reported by Al-Marzooq et $\mathrm{al}^{54}{ }^{5}$ Ngoi et $a{ }^{55}$ Zeng et al, ${ }^{56}$ and Guimarães et al. ${ }^{57}$ On the other hand, the identified mutations are different from those observed by Azargun et al. ${ }^{58}$ Resistance of Enterobacteriaceae to quinolones have been reported with alterations in genes other than the gyrA and parC. Lindbäck, Rahman, Jalal, Wretlind ${ }^{59}$ and others have related mutation in $g y r \mathrm{~B}$ and par $\mathrm{E}$ to resistance to quinolones. $^{60}$ No other mutations were observed in parC, however, other investigators have reported a Glu84Val substitution as the most common mutation in the parC gene. ${ }^{61}$
The presence of PMQR determinants on mobile genetic elements may leads to their dissemination among the Enterobacteriaceae family. ${ }^{62}$ Most of our isolates carried the PMQR determinants. The fact that these genes are on mobile genetic elements constitutes a high risk of rapid dissemination to other Gram-negative bacteria. ${ }^{63}$ The most common PMQR gene observed was the $a a c(6)-I b$, which is consistent with other reports. ${ }^{63,64}$ It was reported that $a a c(6) I b$ gene is common in Enterobacteriaceae and codes for resistance to gentamycin, tobramycin, kanamycin, and amikacin, and this explain the high percentage of this type of resistance in Klebsiella pneumoniae. ${ }^{65,66}$ Among the qnr group of PMQR, qnrB was the most prevalent. Other investigators have also reported the predominance of qnrB type of PMQR in ciprofloxacin resistant isolates. ${ }^{58,67}$ However the frequency of qnrB is higher than that 

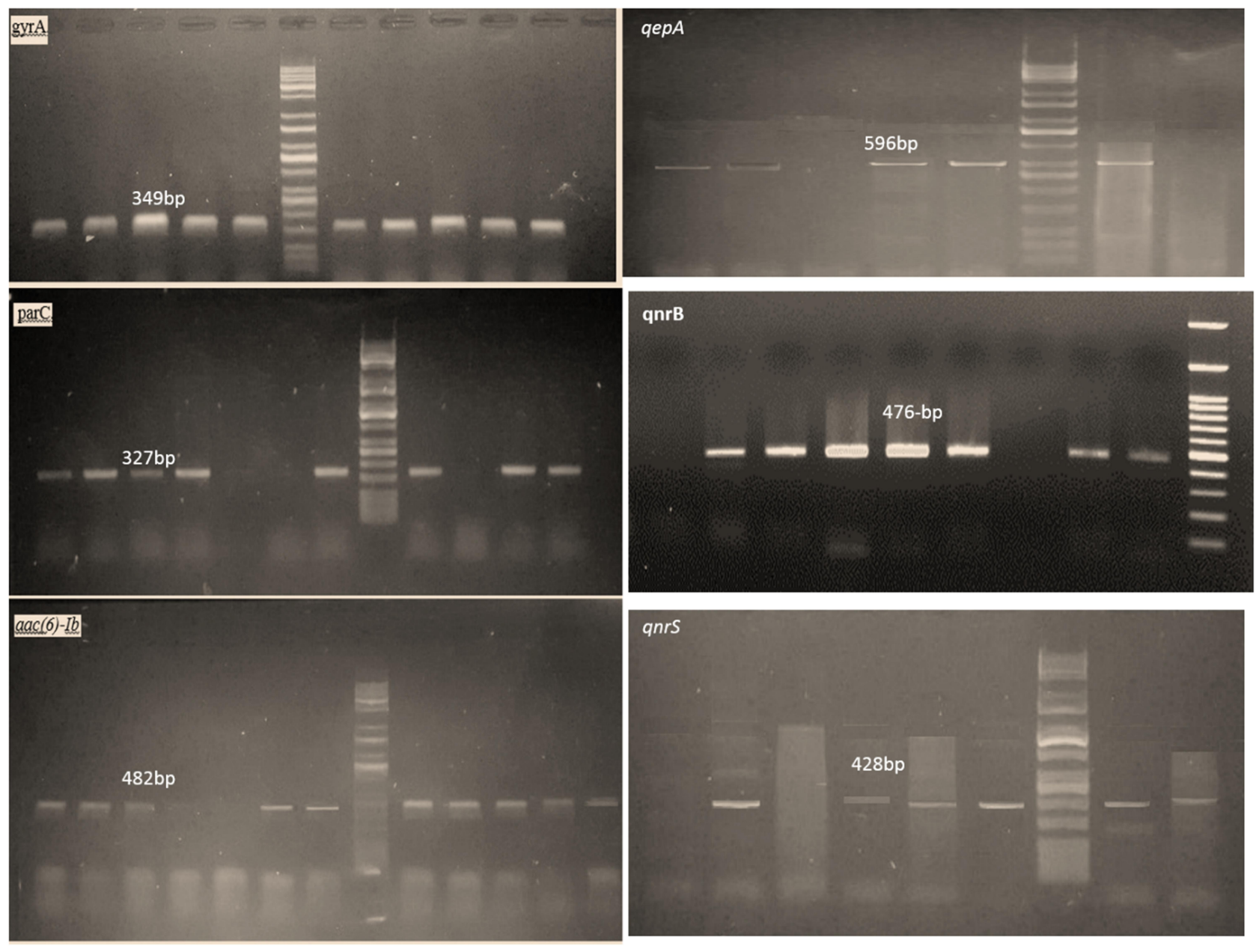

Figure 2 Gel electrophoresis for gyrAparCaac(6)lb, qepAqnrB, andqnrS genes.

observed in other countries such Iran, Korea, and China $\left(21.7 \%, 3.9 \%\right.$ and $2.5 \%$, respectively). ${ }^{58,63,68}$ The differences in the incidence of mutations in DNA gyrase, and topoisomerase IV or prevalence of PMQR determinants could be related to the frequency of fluoroquinolones prescription, study area and period.

The EtBr-agar cartwheel screening method showed efflux activity in 27 strains. Efflux systems have a critical role in development mechanistic drug resistance in Gram-negative bacteria, these pump solutes out of the cell, permitting to microorganism to adjust their internal environment by getting out toxic substance like metabolite, antimicrobial agents, and quorum sensing signal molecules. ${ }^{69}$ Our study reveals the emergence of efflux pump-mediated drug resistance in MDR Gram-negative bacteria in Iraq.

In fact, Gram-negative pathogens rely on tripartite protein assemblies that span their double membrane to pump antibiotics from the cell. The tripartite complex

consists of an inner membrane protein (IMP) of the resistance nodulation cell division (RND) family, outermembrane protein (OMP), and a periplas-mic membrane fusion protein (MFP) which connect the other two proteins. Efflux-mediated drug resistance is prominent in clinically significant MDR Gram-negative bacteria. ${ }^{29,70}$

\section{Conclusions}

Quinolone resistance is common in K. pneumoniae isolates in Baghdad. The frequent mutation in $g y r \mathrm{~A}$ and $\operatorname{par} \mathrm{C}$, and the presence of PMQR genes is alarming.

\section{Acknowledgments}

The authors would like to thank Mustansiriyah University (https://uomustansiriyah.edu.iq/)/Baghdad, Iraq for its support to complete this work. The authors extend their appreciation to the Researchers supporting Project Number (RSP-2020/120) King Saud University, Riyadh, Saudi Arabia. 


\section{Author Contributions}

All authors made a significant contribution to the work reported, whether that is in the conception, study design, execution, acquisition of data, analysis and interpretation, or in all these areas; took part in drafting, revising or critically reviewing the article; gave final approval of the version to be published; have agreed on the journal to which the article has been submitted; and agree to be accountable for all aspects of the work.

\section{Disclosure}

The authors declare no conflicts of interest in this work.

\section{References}

1. El-Sayed M, Algammal A, Abouel-Atta M, Mabrok M, Emam A. Pathogenicity, genetic typing, and antibiotic sensitivity of Vibrio alginolyticus isolated from Oreochromis niloticus and Tilapia zillii. Rev Med Vet.2019;170:80-86.

2. Algammal AM, Enany ME, El-Tarabili RM, Ghobashy MOI, Helmy, YA. Prevalence, Antimicrobial Resistance Profiles, Virulence and Enterotoxins-Determinant Genes of MRSA Isolated from Subclinical Bovine Mastitis in Egypt. Pathogens (Basel, Switzerland). 2020;9(5).

3. Algammal AM, Hetta HF, Elkelish A, et al. Methicillin-Resistant Staphylococcus aureus (MRSA): one health perspective approach to the bacterium epidemiology, virulence factors, antibiotic-resistance, and zoonotic impact. Infect Drug Resist. 2020;13:3255-3265. doi:10.2147/IDR.S272733

4. Algammal AM, Mabrok M, Sivaramasamy E, et al. Emerging MDR-Pseudomonas aeruginosa in fish commonly harbor oprL and toxA virulence genes and bla(TEM), bla(CTX-M), and tetA antibiotic-resistance genes. Sci Rep. 2020;10(1):15961. doi:10.1038/ s41598-020-72264-4

5. Algammal AM, Mohamed MF, Tawfiek BA, Hozzein WN, El Kazzaz WM, Mabrok M. Molecular typing, antibiogram and PCR-RFLP based detection of Aeromonas hydrophila complex isolated from Oreochromis niloticus. Pathogens (Basel, Switzerland). 2020;9:3.

6. Algammal AM, El-Kholy AW, Riad EM, et al. Genes encoding the virulence and the antimicrobial resistance in enterotoxigenic and shiga-toxigenic E. coli isolated from Diarrheic Calves. Toxins. 2020;12(6):383. doi:10.3390/toxins 12060383

7. Algammal AM, El-Sayed ME, Youssef FM, et al. Prevalence, the antibiogram and the frequency of virulence genes of the most predominant bacterial pathogens incriminated in calf pneumonia. $A M B$ Express. 2020;10(1):99. doi:10.1186/s13568-020-01037-z

8. El-Kazzaz W, Metwally L, Yahia R, Al-Harbi N, El-Taher A, Hetta HF. Antibiogram, prevalence of OXA carbapenemase encoding genes, and RAPD-genotyping of multidrug-resistant Acinetobacter baumannii incriminated in hidden community-acquired infections. Antibiotics (Basel, Switzerland). 2020;9(9). doi:10.3390/antibiotics9090603

9. Abd El-Baky RM, Masoud SM, Mohamed DS, et al. Prevalence and some possible mechanisms of colistin resistance among multidrug-resistant and extensively drug-resistant Pseudomonas aeruginosa. Infect Drug Resist. 2020;13:323-332. doi:10.2147/IDR. S238811

10. Abo-Shama UH, El-Gendy H, Mousa WS, et al. Synergistic and antagonistic effects of metal nanoparticles in combination with antibiotics against some reference strains of pathogenic microorganisms. Infect Drug Resist. 2020;13:351-362. doi:10.2147/IDR.S234425
11. Al-Kadmy IMS, Ibrahim SA, Al-Saryi N, Aziz SN, Besinis A, Hetta HF. Prevalence of genes involved in colistin resistance in acinetobacter baumannii: first report from Iraq. Microb Drug Resist. 2020;26(6):616-622. doi:10.1089/mdr.2019.0243

12. El-Mokhtar MA, Hassanein KM, Ahmed AS, Gad GF, Amin MM, Hassanein OF. Antagonistic activities of cell-free supernatants of lactobacilli against extended-spectrum beta-lactamase producing Klebsiella pneumoniae and Pseudomonas aeruginosa. Infect Drug Resist. 2020;13:543-552. doi:10.2147/IDR.S235603

13. Tsay R-W, Siu L, Fung C-P, Chang F-Y. Characteristics of bacteremia between community-acquired and nosocomial Klebsiella pneumoniae infection: risk factor for mortality and the impact of capsular serotypes as a herald for community-acquired infection. Arch Intern Med. 2002;162(9):1021-1027. doi:10.1001/archinte.162.9.1021

14. Andriole VT. The quinolones: past, present, and future. Clin Infect Dis. 2005;41(Supplement_2):S113-S119. doi:10.1086/428051

15. Abd El-Baky RM, Sandle T, John J, Abuo-Rahma GEA, Hetta HF. A novel mechanism of action of ketoconazole: inhibition of the NorA efflux pump system and biofilm formation in multidrug-resistant Staphylococcus aureus. Infect Drug Resist. 2019;12:1703-1718.

16. Elgendy SG, Abdel Hameed MR, El-Mokhtar MA. Tigecycline resistance among Klebsiella pneumoniae isolated from febrile neutropenic patients. J Med Microbiol. 2018;67(7):972-975. doi:10.1099/jmm.0.000770

17. Brisse S, Milatovic D, Fluit AC, Verhoef J, Schmitz FJ. Epidemiology of quinolone resistance of Klebsiella pneumoniae and Klebsiella oxytoca in Europe. Eur J Clin Microbiol Infect Dis. 2000;19(1):64-68. doi:10.1007/s100960050014

18. Usai D, Donadu M, Bua A, et al. Enhancement of antimicrobial activity of pump inhibitors associating drugs. J Infect Dev Ctries. 2019;13(2):162-164. doi:10.3855/jidc. 11102

19. Bilal S, Kareem S. Sensitivity of bacteria Escherichia coli iisolated from urinary tract infection toward ciprofloxacin and lomefloxacin. Ibn Al Haitham J Pure Appl Sci. 2011;24(2):47-61.

20. Ruiz J. Mechanisms of resistance to quinolones: target alterations, decreased accumulation and DNA gyrase protection. J Antimicrob Chemother. 2003;51(5):1109-1117. doi:10.1093/jac/dkg222

21. Martínez-Martínez L, Pascual A, Jacoby GA. Quinolone resistance from a transferable plasmid. Lancet. 1998;351(9105):797-799. doi:10.1016/S0140-6736(97)07322-4

22. Tran JH, Jacoby GA. Mechanism of plasmid-mediated quinolone resistance. Proc Natl Acad Sci U S A. 2002;99(8):5638-5642. doi:10.1073/pnas.082092899

23. Kim HB, Park CH, Kim CJ, Kim E-C, Jacoby GA, Hooper DC. Prevalence of plasmid-mediated quinolone resistance determinants over a 9-year period. Antimicrob Agents Chemother. 2009;53 (2):639-645. doi:10.1128/AAC.01051-08

24. Robicsek A, Strahilevitz J, Jacoby GA, et al. Fluoroquinolonemodifying enzyme: a new adaptation of a common aminoglycoside acetyltransferase. Nat Med. 2006;12(1):83. doi:10.1038/nm1347

25. Jacoby GA, Strahilevitz J, Hooper DC. Plasmid-mediated quinolone resistance. Microbiol Spectr. 2014;2(5). doi:10.1128/microbiolspec. PLAS-0006-2013

26. Veleba M, Higgins PG, Gonzalez G, Seifert H, Schneiders T. Characterization of RarA, a novel AraC family multidrug resistance regulator in Klebsiella pneumoniae. Antimicrob Agents Chemother. 2012;56(8):4450-4458. doi:10.1128/AAC.00456-12

27. Périchon B, Courvalin P, Galimand M. Transferable resistance to aminoglycosides by methylation of G1405 in $16 \mathrm{~S}$ rRNA and to hydrophilic fluoroquinolones by QepA-mediated efflux in Escherichia coli. Antimicrob Agents Chemother. 2007;51 (7):2464-2469. doi:10.1128/AAC.00143-07

28. Liu J-H, Deng Y-T, Zeng Z-L, et al. Coprevalence of plasmidmediated quinolone resistance determinants QepA, Qnr, and AAC (6')-Ib-cr among 16S rRNA methylase RmtB-producing Escherichia coli isolates from pigs. Antimicrob Agents Chemother. 2008;52 (8):2992-2993. doi:10.1128/AAC.01686-07 
29. Venter H, Mowla R, Ohene-Agyei T, Ma S. RND-type drug efflux pumps from gram-negative bacteria: molecular mechanism and inhibition. Front Microbiol. 2015;6:377. doi:10.3389/fmicb.201 5.00377

30. Clinical, Institute LS. Performance Standards for Antimicrobial Susceptibility Testing of Anaerobic Bacteria: Informational Supplement. Clinical and Laboratory Standards Institute (CLSI); 2009.

31. Costa S, Junqueira E, Palma C, et al. Resistance to antimicrobials mediated by efflux pumps in Staphylococcus aureus. Antibiotics. 2013;2(1):83-99. doi:10.3390/antibiotics2010083

32. Martins M, Couto I, Viveiros M, Amaral L. Identification of effluxmediated multi-drug resistance in bacterial clinical isolates by two simple methods. In: Antibiotic Resistance Protocols. Springer; Humana Press.2010:143-157.

33. Thabit AG, El-Sabour A, Nafie AMA, El-Mokhtar MA, Biomy YE. Detection of proteus species in diabetic wounds and their antibiotic resistance profile analysis. Bull Pharm Sci. 2020;43(1):1-10. doi:10.21608/bfsa.2020.93523

34. El-Mokhtar MA, Mandour SA, Shahat AA. Colistin resistance among multidrug-resistant E. coli isolated from Upper Egypt. Egypt $J$ Med Microbiol. 2019;28:11-17.

35. Ardebili A, Lari AR, Beheshti M, Lari ER. Association between mutations in gyrA and parC genes of Acinetobacter baumannii clinical isolates and ciprofloxacin resistance. Iran J Basic Med Sci. 2015;18(6):623.

36. Alshammari MMM, Al-Skhattat HA. Detection of plasmid-mediated quinolone resistance genes in clinical and environmental hospital isolates of Klebsiella pneumoniae in Al-Najaf City pneumoniae Klebsiella. Kufa J Nurs Sci. 2015;5(2):84-92.

37. Hassan AT, Mohamed SA, Mohamed MS, El-Mokhtar MA. Acute exacerbations of chronic obstructive pulmonary disease: etiological bacterial pathogens and antibiotic resistance in Upper Egypt. Egypt $J$ Bronchol. 2016;10(3):283. doi:10.4103/1687-8426.193640

38. Eltwisy HO, Abdel-Fattah M, Elsisi AM, Omar MM, Abdelmoteleb AA, El-Mokhtar MA. Pathogenesis of Staphylococcus haemolyticus on primary human skin fibroblast cells. Virulence. 2020;11(1):1142-1157. doi:10.1080/21505594.20 20.1809962

39. El-Mokhtar MA, Hetta HF. Ambulance vehicles as a source of multidrug-resistant infections: a multicenter study in Assiut City, Egypt. Infect Drug Resist. 2018;11:587. doi:10.2147/IDR.S151783

40. Ramadan HK, Mahmoud MA, Aburahma MZ, et al. Predictors of severity and co-infection resistance profile in COVID-19 patients: first report from Upper Egypt. Infect Drug Resist. 2020;13:3409-3422. doi:10.2147/IDR.S272605

41. Ahmed S, Ahmed S, Mohamed W, et al. Nosocomial vancomycin and methicillin resistant staphylococcal infections in intensive care units in Assiut University Hospitals. Egypt J Med Microbiol. 2011;20(2).

42. Abd Ellah NH, Abdel-Aleem JA, Abdo MN, Abou-Ghadir OF, Zahran KM, Hetta HF. Efficacy of ketoconazole gel-flakes in treatment of vaginal candidiasis: formulation, in vitro and clinical evaluation. Int $J$ Pharm. 2019;567:118472. doi:10.1016/j. ijpharm.2019.118472

43. Kim JY, Jeon SM, Kim H, Lim N, Park MS, Kim SH. Resistance to fluoroquinolone by a combination of efflux and target site mutations in enteroaggregative Escherichia coli Isolated in Korea. Osong Public Health Res Perspect. 2012;3(4):239-244.

44. Robicsek A, Jacoby GA, Hooper DC. The worldwide emergence of plasmid-mediated quinolone resistance. Lancet Infect Dis. 2006;6 (10):629-640. doi:10.1016/S1473-3099(06)70599-0

45. Abd El-Baky RM, Farhan SM, Ibrahim RA, Mahran KM, Hetta HF. Antimicrobial resistance pattern and molecular epidemiology of ESBL and MBL producing Acinetobacter baumannii isolated from hospitals in Minia, Egypt. Alexandria J Med. 2020;56(1):4-13. doi:10.1080/20905068.2019.1707350
46. Mirzaii M, Jamshidi S, Zamanzadeh M, et al. Determination of gyrA and parC mutations and prevalence of plasmid-mediated quinolone resistance genes in Escherichia coli and Klebsiella pneumoniae isolated from patients with urinary tract infection in Iran. $J$ Glob Antimicrob Resist. 2018;13:197-200. doi:10.1016/j.jgar.2018.04.017

47. Varughese LR, Rajpoot M, Goyal S, Mehra R, Chhokar V, Beniwal V. Analytical profiling of mutations in quinolone resistance determining region of gyrA gene among UPEC. PLoS One. 2018;13(1):e0190729.

48. Esmaeel NE, Gerges MA, Hosny TA, Ali AR, Gebriel MG, Resistance D. Detection of chromosomal and plasmid-mediated quinolone resistance among Escherichia coli Isolated from urinary tract infection cases; Zagazig University Hospitals, Egypt. Infect Drug Resist. 2020;13:413. doi:10.2147/IDR.S240013

49. Jacoby GA. Mechanisms of resistance to quinolones. Clin Infect Dis. 2005;41(Suppl 2):S120-S126. doi:10.1086/428052

50. Sorlozano A, Gutierrez J, Jimenez A, de Dios Luna J, Martinez JL. Contribution of a new mutation in parE to quinolone resistance in extended-spectrum-beta-lactamase-producing Escherichia coli isolates. J Clin Microbiol. 2007;45(8):2740-2742. doi:10.1128/ JCM.01093-07

51. Fàbrega A, Madurga S, Giralt E, Vila J. Mechanism of action of and resistance to quinolones. Microb Biotechnol. 2009;2(1):40-61. doi:10.1111/j.1751-7915.2008.00063.x

52. Lee JK, Lee YS, Park YK, Kim BS. Mutations in the gyrA and parC genes in ciprofloxacin-resistant clinical isolates of Acinetobacter baumannii in Korea. Microbiol Immunol. 2005;49(7):647-653. doi:10.1111/j.1348-0421.2005.tb03643.x

53. Minarini LA, Darini ALC. Mutations in the quinolone resistance-determining regions of gyrA and parC in Enterobacteriaceae isolates from Brazil. Braz J Microbiol. 2012;43 (4):1309-1314. doi:10.1590/S1517-83822012000400010

54. Al-Marzooq F, Mohd Yusof MY, Tay ST. Molecular analysis of ciprofloxacin resistance mechanisms in Malaysian ESBL-producing Klebsiella pneumoniae isolates and development of Mismatch Amplification Mutation Assays (MAMA) for rapid detection of gyrA and parC mutations. Biomed Res Int. 2014;2014:601630. doi: $10.1155 / 2014 / 601630$

55. Ngoi ST, Thong KL. High resolution melting analysis for rapid mutation screening in gyrase and topoisomerase IV genes in quinolone-resistant Salmonella enterica. Biomed Res Int. 2014;2014:718084. doi:10.1155/2014/718084

56. Zeng L, Zhang J, Li C, et al. The determination of gyrA and parC mutations and the prevalence of plasmid-mediated quinolone resistance genes in carbapenem resistant Klebsiella pneumonia ST11 and ST76 strains isolated from patients in Heilongjiang Province, China. Infect Genet Evol. 2020;82:104319. doi:10.1016/j.meegid.2020.104319

57. Guimarães B, Barreto A, Radhouani H, et al. Genetic detection of extended-spectrum beta-lactamase-containing Escherichia coli isolates and vancomycin-resistant enterococci in fecal samples of healthy children. Microb Drug Resist. 2009;15(3):211-216. doi:10.1089/mdr.2009.0910

58. Azargun R, Soroush Barhaghi MH, Samadi Kafil H, et al. Frequency of DNA gyrase and topoisomerase IV mutations and plasmid-mediated quinolone resistance genes among Escherichia coli and Klebsiella pneumoniae isolated from urinary tract infections in Azerbaijan, Iran. J Glob Antimicrob Resist. 2019;17:39-43. doi:10.1016/j.jgar.2018.11.003

59. Lindbäck E, Rahman M, Jalal S, Wretlind BJA. Mutations in gyrA, gyrB, parC, and parE in quinolone-resistant strains of Neisseria gonorrhoeae. Apmis. 2002;110(9):651-657. doi:10.1034/j.16000463.2002.1100909.x

60. Eaves DJ, Randall L, Gray DT, et al. Prevalence of mutations within the quinolone resistance-determining region of gyrA, gyrB, parC, and parE and association with antibiotic resistance in quinolone-resistant Salmonella enterica. Antimicrob Agents Chemother. 2004;48 (10):4012-4015. doi:10.1128/AAC.48.10.4012-4015.2004 
61. Betitra Y, Teresa V, Miguel V, Abdelaziz T. Determinants of quinolone resistance in Escherichia coli causing community-acquired urinary tract infection in Bejaia, Algeria. Asian Pac J Trop Med. 2014;7 (6):462-467. doi:10.1016/S1995-7645(14)60075-4

62. Carattoli A. chemotherapy. Resistance Plasmid Families in Enterobacteriaceae. 2009;53(6):2227-2238.

63. Yang HY, Nam YS, HJ L, Microbiology M. Prevalence of plasmid-mediated quinolone resistance genes among ciprofloxacin-nonsusceptible Escherichia coli and Klebsiella pneumoniae isolated from blood cultures in Korea. Can J Infect Dis Med Microbiol. 2014;25.

64. Shams E, Firoozeh F, Moniri R, Zibaei M. Prevalence of plasmid-mediated quinolone resistance genes among extended-spectrum beta -lactamase-producing Klebsiella pneumoniae human isolates in Iran. J Pathog. 2015;2015:434391. doi:10.1155/ 2015/434391

65. Kim Y-T, Jang J-H, Kim H-C, et al. Identification of strain harboring both aac (6)-Ib and aac (6)-Ib-cr variant simultaneously in Escherichia coli and Klebsiella pneumoniae. BMB Rep. 2011;44 (4):262-266. doi:10.5483/BMBRep.2011.44.4.262
66. Al-Jubori S, Al-Kadmy I, Jassim Al Ani IZ. Emergence of Multidrug resistance (MDR) Acinetobacter baumannii isolated from Iraqi hospitals. Adv Environ Biol. 2016;10: 265-276.

67. Minarini LA, Poirel L, Cattoir V, Darini ALC, Nordmann P. Plasmidmediated quinolone resistance determinants among enterobacterial isolates from outpatients in Brazil. $J$ Antimicrob Chemother. 2008;62(3):474-478. doi:10.1093/jac/dkn237

68. Jiang Y, Zhou Z, Qian Y, et al. Plasmid-mediated quinolone resistance determinants qnr and aac(6')-Ib-cr in extended-spectrum betalactamase-producing Escherichia coli and Klebsiella pneumoniae in China. J Antimicrob Chemother. 2008;61(5):1003-1006. doi:10.1093/ $\mathrm{jac} / \mathrm{dkn} 063$

69. Nikaido H, Pagès J-M. Broad-specificity efflux pumps and their role in multidrug resistance of gram-negative bacteria. FEMS Microbiol Rev. 2012;36(2):340-363. doi:10.1111/j.1574-6976.2011.00290.x

70. Algammal AM, Hetta HF, Batiha GE, et al. Virulence-determinants and antibiotic-resistance genes of MDR-E. coli isolated from secondary infections following FMD-outbreak in cattle. Sci Rep. 2020;10:19779. doi:10.1038/s41598-020-75914-9
Infection and Drug Resistance

\section{Publish your work in this journal}

Infection and Drug Resistance is an international, peer-reviewed openaccess journal that focuses on the optimal treatment of infection (bacterial, fungal and viral) and the development and institution of preventive strategies to minimize the development and spread of resistance. The journal is specifically concerned with the epidemiology of
Dovepress

antibiotic resistance and the mechanisms of resistance development and diffusion in both hospitals and the community. The manuscript management system is completely online and includes a very quick and fair peerreview system, which is all easy to use. Visit http://www.dovepress.com/ testimonials.php to read real quotes from published authors. 